\title{
Anti-Tumor Effect of Rutin on Human Neuroblastoma Cell Lines through Inducing G2/M Cell Cycle Arrest and Promoting Apoptosis
}

\author{
Hongyan Chen, ${ }^{1}$ Qing Miao, ${ }^{2}$ Miao Geng, ${ }^{1}$ Jing Liu, ${ }^{1}$ Yazhuo Hu, ${ }^{1}$ Lei Tian, \\ Jingkun Pan, ${ }^{1}$ and Yi Yang ${ }^{3}$ \\ ${ }^{1}$ Beijing Key Laboratory for Aging and Geriatrics, Institute of Geriatrics, General Hospital of Chinese PLA, Beijing, China \\ ${ }^{2}$ National Institute of Occupational Health and Poison Control, Chinese Center for Disease Control and Prevention, Beijing, China \\ ${ }^{3}$ Minzu University of China, Beijing, China
}

Correspondence should be addressed to Miao Geng; gengmiao_2006@sina.com

Received 14 October 2013; Accepted 7 November 2013

Academic Editors: C.-L. Hsieh, B.-Y. Zeng, and K. Zhao

Copyright (c) 2013 Hongyan Chen et al. This is an open access article distributed under the Creative Commons Attribution License, which permits unrestricted use, distribution, and reproduction in any medium, provided the original work is properly cited.

\begin{abstract}
Aims. To further investigate the antineuroblastoma effect of rutin which is a type of flavonoid. Methods. The antiproliferation of rutin in human neuroblastoma cells LAN-5 were detected by 3-(4,5-dimethylthiazol-2-yl)-2,5-diphenyltetrazolium bromide (MTT) assay. Chemotaxis of LAN-5 cells was assessed using transwell migration chambers and scratch wound migration assay. The cell cycle arrest and apoptosis in a dose-dependent manner was measured by flow cytometric and fluorescent microscopy analyses. The apoptosis-related proteins BAX and BCL2 as well as MYCN mRNA express were determined by RT-PCR analysis. Secreted TNF- $\alpha$ level were determined using specific enzyme-linked immunosorbent assay kits. Results. Rutin significantly inhibited the growth of LAN-5 cells and chemotactic ability. Flow cytometric analysis revealed that rutin induced G2/M arrest in the cell cycle progression and induced cell apoptosis. The RT-PCR showed that rutin could decrease BCL2 expression and BCL2/BAX ratio. In the meantime, the MYCN mRNA level and the secretion of TNF- $\alpha$ were inhibited. Conclusion. These results suggest that rutin produces obvious antineuroblastoma effects via induced G2/M arrest in the cell cycle progression and induced cell apoptosis as well as regulating the expression of gene related to apoptosis and so on. It supports the viability of developing rutin as a novel therapeutic prodrug for neuroblastoma treatment, as well as providing a new path on anticancer effect of Chinese traditional drug.
\end{abstract}

\section{Introduction}

Neuroblastoma (NB) is the most common extracranial solid tumor in childhood, and it is the most common type of cancer to be diagnosed in the first year of life [1]. While the overall survival rate for children with low- and intermediaterisk NB has been consistently improved, less than $40 \%$ of high-risk NB patients survive, in spite of the intensification of the multiagent induction therapy, along with surgery [2]. Consequently, further advances in therapy are necessary to target NB tumor cells in a more efficient way to gain clinical benefits without substantially increasing toxicity.

The first recorded use of herbs for medical treatment begun 4000 years ago, originating from China and India. Recently, increasing attention has been focused on the application of herbs in tumor therapy all over the world. Traditional Chinese medicine has multieffects, being immunomodulatory and anti-inflammatory as well as inducing apoptosis; it may also function as radiosensitizers during the radiotherapy of cancer [3]. Advantages of Chinese medicine are providing treatment method for Patients who lost surgical and chemotherapy opportunity. Flavonoids are polyphenolic compounds that are ubiquitously in plants. The flavonoids have aroused considerable interest recently because of their potential beneficial effects on human health; they have been reported to have antiviral, antiallergic, antiplatelet, anti-inflammatory, antitumor, and antioxidant activities [4-6]. In a 20-year study, it was found that participants with the highest intake of flavonoids and proanthocyanidins had a 44 and 40 percent lower risk of oral 
<smiles>C[C@H]1O[C@H](OC[C@H]2O[C@@H](Oc3c(-c4ccc(O)c(O)c4)oc4cc(O)cc(O)c4c3=O)[C@H](O)[C@H](O)[C@H]2O)[C@H](O)[C@@H](O)[C@H]1O</smiles>

FIgURE 1: The chemical structure of rutin.

cancer and laryngeal cancer, respectively, and the occurrence of colon cancer was also lowered by a third, and there were reductions in breast, kidney, and ovarian cancers too [7]. Based on these results, flavonoids may be promising anticancer agents. Rutin (quercetin rutinoside) (Figure 1) is a glycoside of the flavonoid quercetin. Many beneficial effects of rutin have been identified, including inhibition of platelet aggregation, being anti-inflammatory, antioxidant, and reduction of blood fat and cholesterol [8]. The auticancer research showed that rutin could exert significant and potentially beneficial effects on decreasing the amount of precancerous lesions and inducing apoptosis in the large intestine cancer [9], but for the treatment of neuroblastoma effect has not been reported. Therefore, we investigated whether rutin could couse anti-proliferation and induction of apoptosis in human neuroblastoma LAN-5 cells. The results show that rutin produces obvious antineuroblastoma effects via induced G2/M arrest in the cell cycle progression and induced cell apoptosis as well as regulating the expression of gene related to apoptosis.

\section{Experimental Procedures}

2.1. MTT Assay. Cultured LAN-5 cells (the human neuroblastoma cell strain was graciously provided by the Academy of Military Medical Sciences) were digested, suspended in DMEM medium supplemented with $10 \%$ FBS, counted, and inoculated in a 96-well plate at a concentration of $1 \times 10^{4}$ cells per well. One day, after inoculation, the adherent cells were cultured in serum-free DMEM and pretreated with either $0,25,50 \mu \mathrm{M}$, or $100 \mu \mathrm{M}$ rutin (Rutin with purity $>92.5 \%$ was purchased from the National Institute for the Control of Pharmaceutical and Biological Products) for $24 \mathrm{~h}$. The culture media were collected and stored at $-20^{\circ} \mathrm{C}$ for future use, and the cells were reacted with $5 \mathrm{mg} / \mathrm{mL}$ 3-(4,5-dimethylthiazol2-yl)-2,5-diphenyltetrazolium bromide (MTT) solution for $4 \mathrm{~h}$. The reaction was terminated by adding $100 \mu \mathrm{L}$ DMSO, and the absorbance at $570 \mathrm{~nm}$ was determined using an enzyme-linked immunosorbent assay reader.

2.2. Cell Cycle Analysis. Flow cytometric cell cycle analysis was performed as described previously. A density of $1 \times 10^{6}$ cells/well were seeded into 6-well plates and left to attach

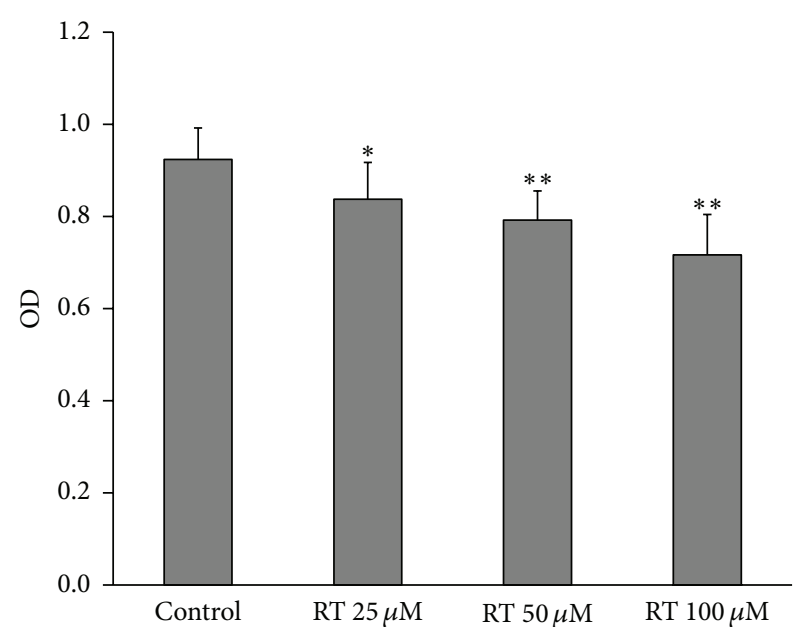

FIGURE 2: The effect of rutin on cell viability. Cells were treated with rutin (RT $25 \mu \mathrm{M}$, RT $50 \mu \mathrm{M}$, or RT $100 \mu \mathrm{M}$ ) for $24 \mathrm{~h}$. Data are shown as the means of three experiments. ${ }^{*} P<0.05 ;{ }^{* *} P<0.01$ compared to control.

overnight, similar to MTT assay. The cells were incubated with $0,25,50$, and $100 \mu \mathrm{M}$ of rutin for $24 \mathrm{~h}$. After incubation, cells were harvested and washed with phosphate buffered saline (PBS), resuspended, and fixed in 75\% ice-cold ethanol overnight at $4^{\circ} \mathrm{C}$. Then the cells were treated with RNase A $(50 \mathrm{mg} / \mathrm{mL})$ and propidium iodide (PI, Sigma) $(50 \mathrm{mg} / \mathrm{mL})$ and analyzed by the Coulter Epics XL Flow Cytometer (Beckman, USA).

2.3. Apoptosis Detection with Flow Cytometry (Double Staining with Annexin V-FITC/PI). The double dye Annexin VFITC/PI was used to distinguish living cells, early and late apoptosis cells, and necrotic cells. LAN-5 cells were treated with different concentrations of rutin for $24 \mathrm{~h}$ as previously described, then harvested and washed with PBS, and then resuspended in the PBS. Cells were stained with Annexin VFITC/PI according to the protocol of Annexin V-FITC cell Apoptosis Detection Kit. After incubation, the samples were pelleted to the Coulter Epics XL Flow Cytometer (Beckman, USA).

2.4. Cytokine Analysis. The collected supernatants from each treatment were incubated at room temperature and were used to measure TNF- $\alpha$ level using specific enzyme-linked immunosorbent assay (ELISA) kits, according to the manufacturer's instruction. The TNF- $\alpha$ cytokine levels are shown as the mean $\pm \mathrm{SD}$ (picograms of each cytokine per milliliter).

2.5. RT-PCR Assay. LAN-5 cells were treated and collected, and total RNA was extracted using the mRNA extraction kit (Beijing Tiandz Gene Engineering, Beijing, China). Nucleic acid concentration was determined using a UV spectrophotometer (Shimadzu, Kyoto, Japan). A total of $2 \mu \mathrm{g}$ total RNA was harvested and reverse-transcribed and synthesized into cDNA according to Fermentas reverse transcriptase kit instructions (Vilnius, Lithuania). A total of $2 \mu \mathrm{L}$ 

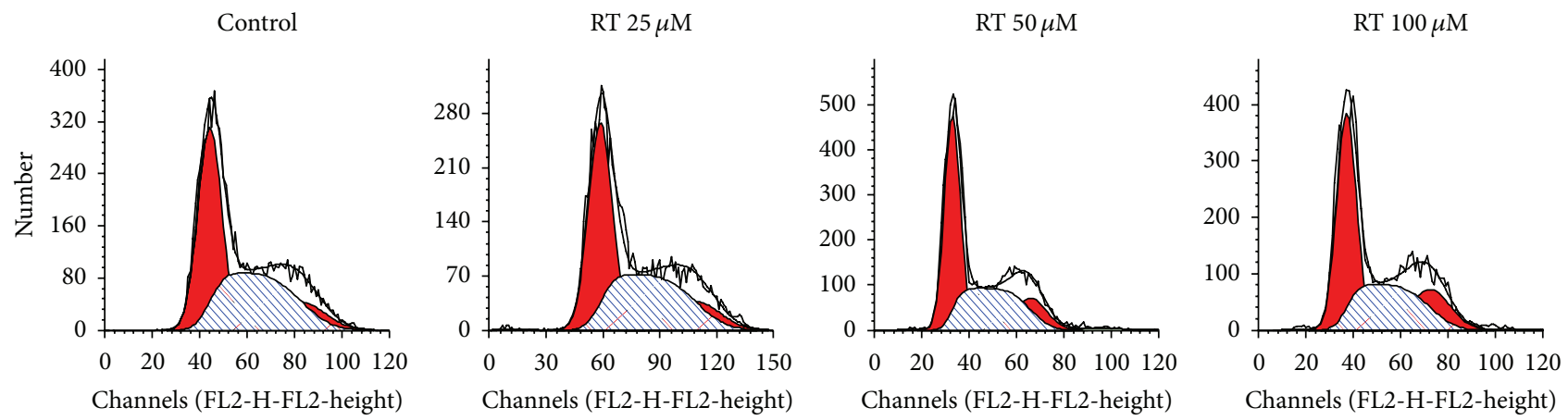

FIgure 3: The effect of rutin on cell cycle. Cells were treated with rutin for $24 \mathrm{~h}$ with designated rutin then washed with PBS to remove complete medium, and fixed with 75\% per-cold alcohol then stained with PI, and the DNA content was analyzed by flow cytometry.

reverse transcription product was amplified using specific primers: $B C L 2$ : forward $5^{\prime}$-TGTGGCCCAGATAGGCACCCAG- $3^{\prime}$ and reverse $5^{\prime}$-ACTTCGCCGAG ATGTCCAGCCAG-3', product 370 bp: BAX: forward $5^{\prime}$-ACCAAGAAGCTGAGCGAGTATC- ${ }^{\prime}$ and reverse $5^{\prime}$-ACAAAGATGGTCACGGTCTGCC- $3^{\prime}$, product $367 \mathrm{bp}$; MYCN: forward, $5^{\prime}$-CTCAGTACCTC CGGAGAG-3' and reverse, $5^{\prime}$-GGCATCGTTTGAGGATC-3' ${ }^{\prime}$ product $177 \mathrm{bp}$; GAPDH: forward $5^{\prime}$-GCCAAAAGGG TCATCA TCTC-3' and reverse 5GGCCATCCACAGTCTTCT-3' product $196 \mathrm{bp}$. For BCL2 PCR conditions were $5 \mathrm{~min}$ at $94^{\circ} \mathrm{C}$, amplification for 30 cycles with $1 \mathrm{~min}$ at $94^{\circ} \mathrm{C}, 1 \mathrm{~min}$ at $58^{\circ} \mathrm{C}$ and a final extension for $1 \mathrm{~min}$ at $72^{\circ} \mathrm{C}$; For BAX PCR conditions were $5 \mathrm{~min}$ at $94^{\circ} \mathrm{C}$, amplification for 30 cycles with $1 \mathrm{~min}$ at $94^{\circ} \mathrm{C}, 1 \mathrm{~min}$ at $60^{\circ} \mathrm{C}$ and a final extension for $1 \mathrm{~min}$ at $72^{\circ} \mathrm{C}$; For MYCN PCR conditions were $5 \mathrm{~min}$ at $94^{\circ} \mathrm{C}$, amplification for 30 cycles with $1 \mathrm{~min}$ at $94^{\circ} \mathrm{C}, 1 \mathrm{~min}$ at $60^{\circ} \mathrm{C}$ and a final extension for $1 \mathrm{~min}$ at $72^{\circ} \mathrm{C}$; For GAPDH PCR conditions were $5 \mathrm{~min}$ at $94^{\circ} \mathrm{C}$, amplification for 30 cycles with $1 \mathrm{~min}$ at $94^{\circ} \mathrm{C}, 1 \mathrm{~min}$ at $56^{\circ} \mathrm{C}$ and a final extension for $1 \mathrm{~min}$ at $72^{\circ} \mathrm{C}$. Products were separated by $2.0 \%$ agarose gel electrophoresis and photographed using a gel imaging analysis system (Shanghai Talent Electronics, Shanghai, China).

2.6. Scratch Wound Migration Assay. A density of $1 \times 10^{5}$ cells/well were seeded into 6-well plates; cells were cultured for approximately $24 \mathrm{~h}$, at which time they were approximately $80 \%$ confluent. The monolayer was scratched with a sterile $200 \mu \mathrm{L}$ pipette tip, and the cells were treated with rutin $(0,25,50,100 \mu \mathrm{M})$ then incubated for a further $48 \mathrm{~h}$ to allow time for migration into the cell-free area.

2.7. Transwell Assay. Chemotaxis in LAN-5 cells was assessed using transwell migration chambers $(8 \mu \mathrm{m}$ pore polycarbonate filters in 24 wells). LAN-5 cells were plated into the top wells $\left(6 \times 10^{4}\right.$ cells per well), which were filled with medium alone or in absence of rutin $(25 \mu \mathrm{M}, 50 \mu \mathrm{M}$, and $100 \mu \mathrm{M})$ and incubated for $24 \mathrm{~h}$ at $37^{\circ} \mathrm{C}$. Cells on the top side of the filter were wiped off using a cotton bud, and cells on the lower surface of the filter were fixed in $100 \%$ methanol for $3 \mathrm{~min}$ and subjected to $4^{\prime}$,6-diamidino-2-phenylindole (DAPI) staining. Then, the cells were counted under a fluorescence microscope (5 fields were examined for each condition).
TABLE 1: The effect of rutin on cell cycle.

\begin{tabular}{lccc}
\hline Rutin $(\mu \mathrm{M})$ & G0/G1 $(\%)$ & $S(\%)$ & G2/M (\%) \\
\hline 0 & $48.57 \pm 2.24$ & $42.63 \pm 2.35$ & $8.8 \pm 1.32$ \\
25 & $46.73 \pm 1.55$ & $43.22 \pm 1.59$ & $10.05 \pm 1.48$ \\
50 & $48.71 \pm 1.69$ & $36.83 \pm 1.21$ & $14.46 \pm 1.43^{*}$ \\
100 & $46.87 \pm 2.11$ & $33.08 \pm 1.04$ & $20.05 \pm 2.18^{* *}$ \\
\hline
\end{tabular}

2.8. Statistical Analysis. All the data were normally distributed; therefore, in instances of single mean comparisons, Levene's test for equality of variances followed by a Student's $t$-test for independent samples was used to assess significance. In instances of multiple mean comparisons, ANOVA was used, followed by post hoc comparisons using Bonferroni's method. The levels were set at 0.05 for all the analyses. The statistical package for the social sciences release 19 (SPSS, SN: 5087722) was used for all the data analyses.

\section{Results}

3.1. Effect of Rutin on Cell Viability of LAN-5 Cells. We first examined the effects of rutin on the viability of LAN-5 cells. The MTT assay (Figure 2) showed that rutin treatment significantly inhibited the viability of LAN-5 cells in a dose dependent manner, OD values from $0.92 \pm 0.06$ to $0.83 \pm 0.07$ and $0.79 \pm 0.06$ as well as $0.71 \pm 0.08$, respectively.

3.2. Rutin Induced Cell Cycle Arrest in G2/M Phase in LAN5 Cells. The effects of rutin on cell cycle progress in LAN5 cells, were investigated by flow cytometry. Cells incubated with different concentrations $(0,25,50$, and $100 \mu \mathrm{M})$ of rutin for $24 \mathrm{~h}$ were analyzed for the distribution of G0/G1, S, and G2/M phases of cell cycle (Figure 3). Compared with control, rutin treatment resulted in a significant accumulation of cells in the G2/M phase, the percentage of LAN-5 cells in the G2/M fraction increased from $8.8 \%$ to $10.05 \%, 14.46 \%$, and $20.05 \%$ after treated with 25,50 , and $100 \mu \mathrm{M}$ of rutin (Table 1), which underwent G2/M arrest in a dose-dependent way.

3.3. Rutin Induced LAN-5 Apoptosis Is Mediated by Induction of BCL2/BAX Imbalance. Annexin V-FITC/PI apoptosis 

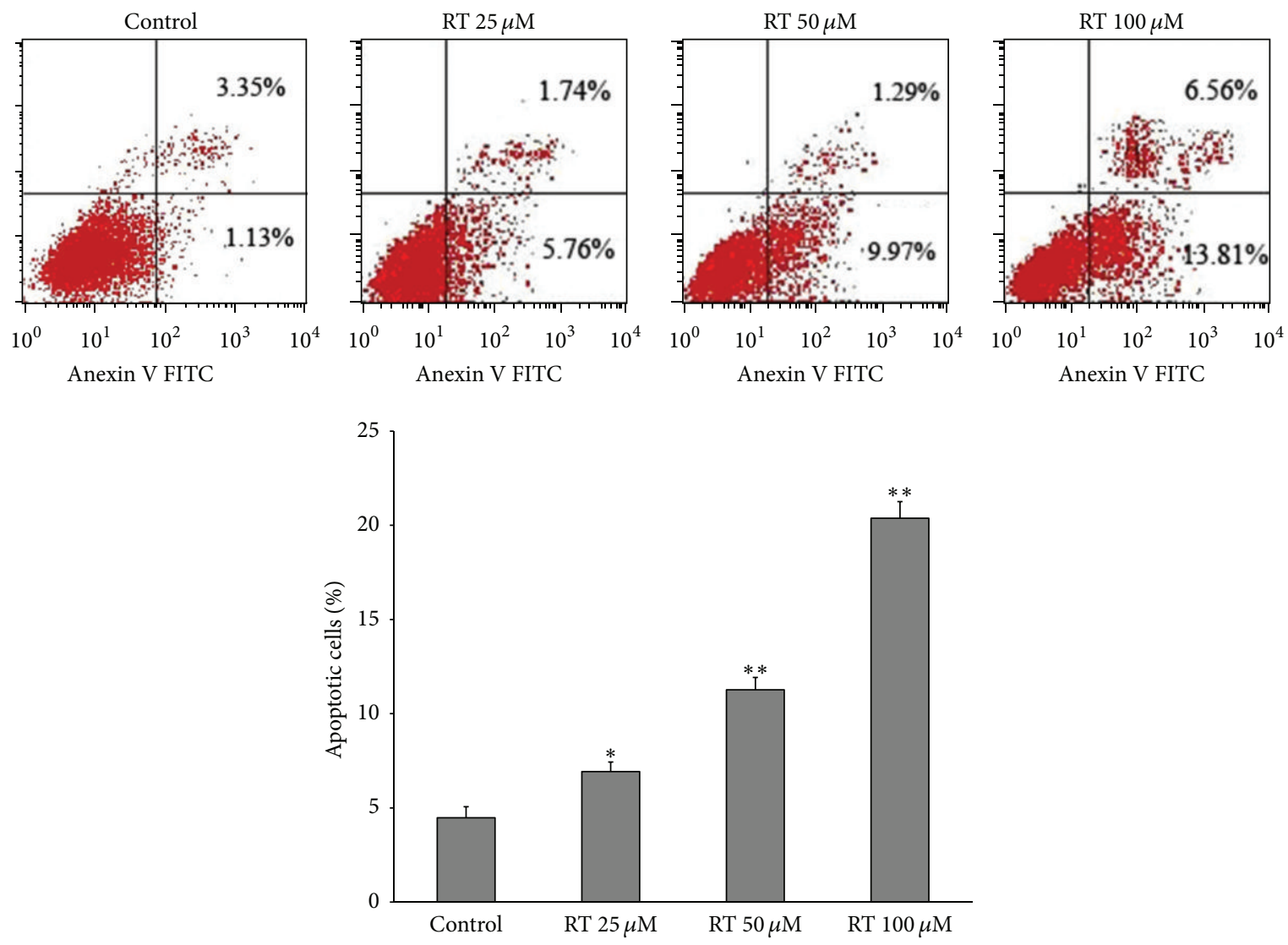

(a)
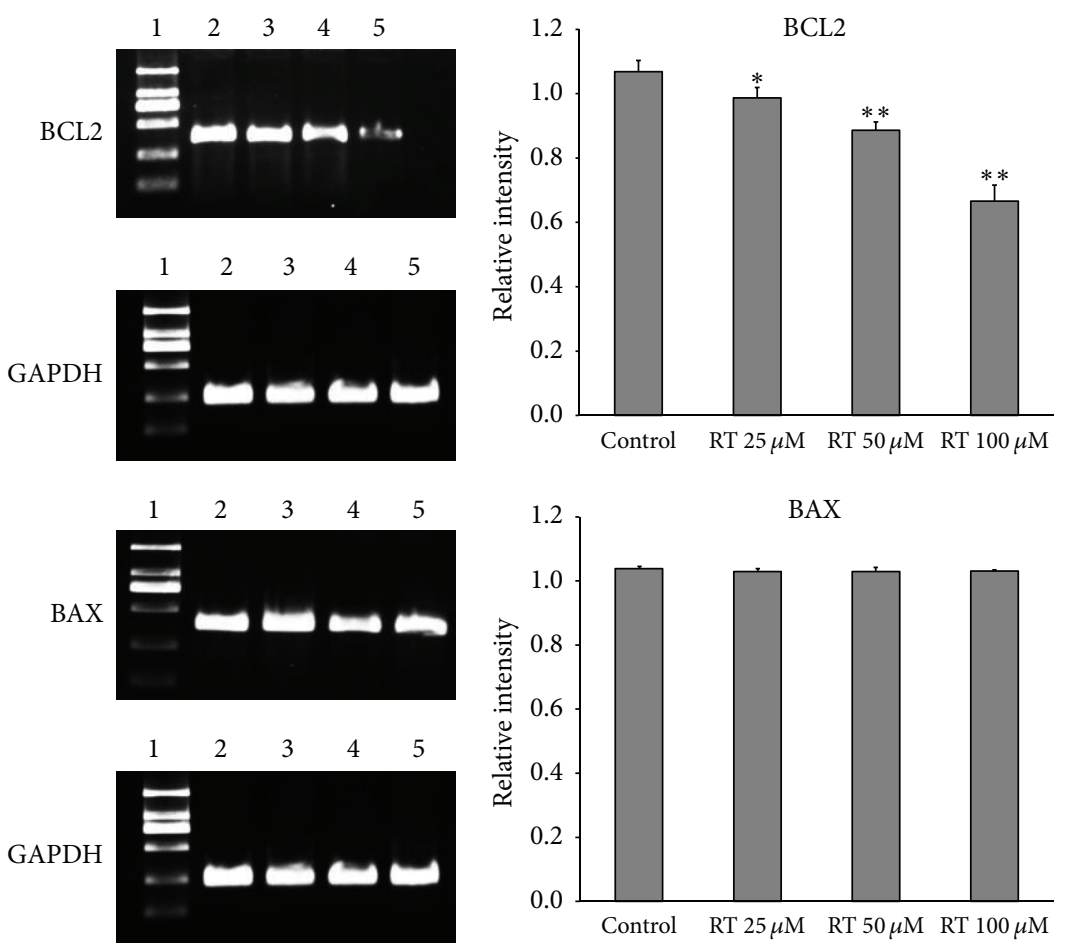

(b)

FIgURE 4: Continued. 


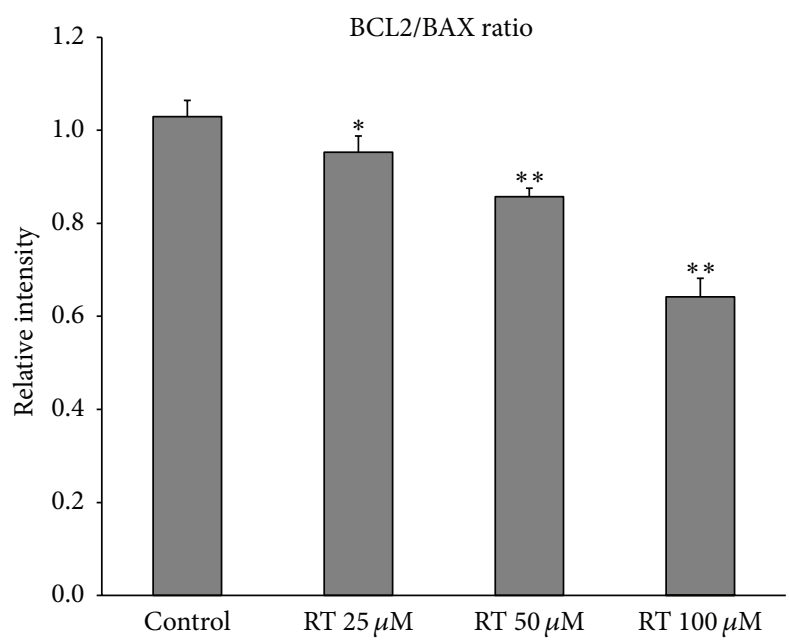

(c)

FIGURE 4: The effect of rutin on cell apoptosis and expression of BCL2 and BAX. (a) Apoptosis rates of LAN-5 incubated with different concentrations of rutin, the percentage of apoptotic cells were measured by flow cytometry using the PI-annexin V assay. (b) Quantification of BCL2 and BAX mRNA levels, (c) calculated BCL2/BAX ratios. The "relative intensity" was defined as the intensity (target mRNA)/intensity (GAPDH). All experiments were repeated three times. ${ }^{*} \mathrm{P}<0.05,{ }^{* *} \mathrm{P}<0.01$ compared to control. 1: marker; 2: control; 3: RT $25 \mu \mathrm{M}$; 4 : RT $50 \mu \mathrm{M} ; 5$ : Rt $100 \mu \mathrm{M}$.

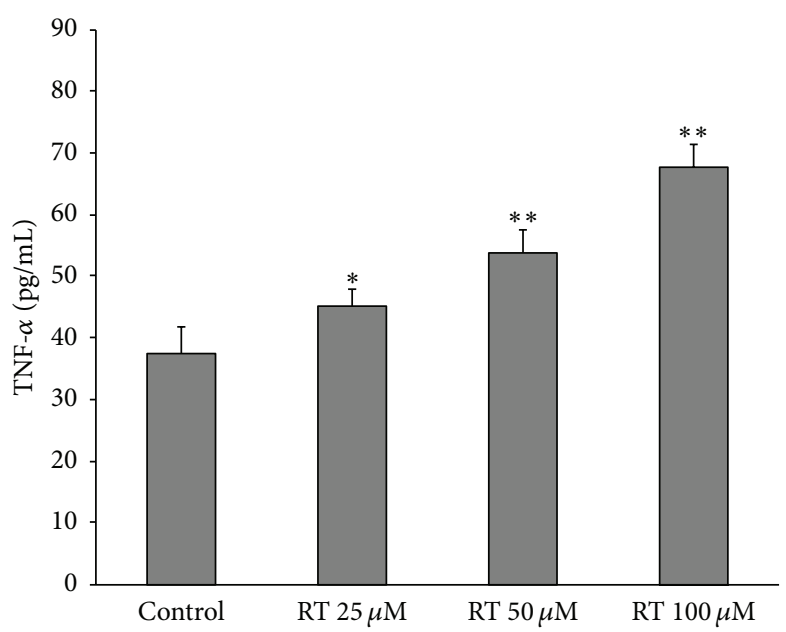

FIGURE 5: The effects of rutin on TNF- $\alpha$ secretion. The results of ELISA measuring TNF- $\alpha$ contents in the supernatants of LAN-5 cells treated with $0,25,50$ and $100 \mu \mathrm{M}$ rutin (RT $25 \mu \mathrm{M}$, RT $50 \mu \mathrm{M}$ or RT $100 \mu \mathrm{M}$ ) for $24 \mathrm{~h}$. Data shown are the means of three experiments. ${ }^{*} P<0.05$; ${ }^{* *} P<0.01$ compared to control.

assay kit was used to detect cell apoptosis (Figure 4(a)). Normal cells were used as the control group. It seems that the addition of different dose rutin induced apoptosis of LAN5 cells with percentages of apoptosis cells increasing from $4.48 \%$ to $7.50 \%, 11.26 \%$, and $20.37 \%$. Meanwhile, RT-PCR analysis showed that the expression of BCL2 was downregulated by rutin and BCL2/BAX ratios were downregulated (Figures 4(b) and 4(c)).

3.4. Effect of Rutin on TNF- $\alpha$ Release in LAN-5 Cells. We further explored the effect of rutin on the secretion of TNF- $\alpha$ in LAN-5 cells. As shown (Figure 5), treatment with $25 \mu \mathrm{M}$ and $50 \mu \mathrm{M}$ or $100 \mu \mathrm{M}$ rutin markedly increased
TNF- $\alpha$ secretion from $37.59 \pm 4.17$ to $44.97 \pm 2.94$ and $53.63 \pm$ 4.0 as well as $67.72 \pm 3.89 \mathrm{pg} / \mathrm{mL}$, respectively.

\subsection{Effect of Rutin on Cell Migration and Invasion Capability.} Cell monolayer wounding and migration test were performed to examine the role of rutin on cell migration. LAN-5 cells were seeded in 6-well plates; wounds were created by scrapping the cell monolayer by P200 pipette tips. As shown in Figure 6(a), different dose rutin could decrease the migration rate of LAN-5 cells, as compared to that of control LAN-5 cells, indicating that rutin is involved in migration capability of LAN-5 cells. Matrigel invasion assay was performed to examine the role of rutin in LAN-5 cell invasion. LAN-5 cells 

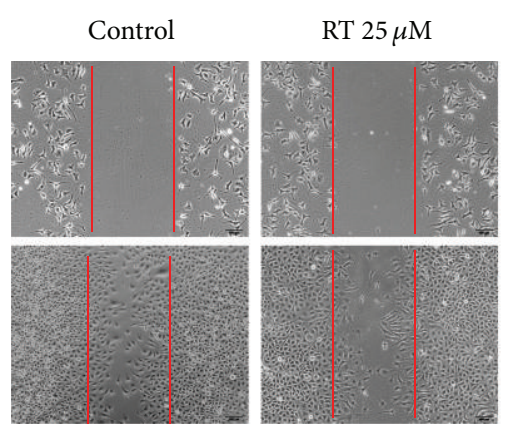

(a)

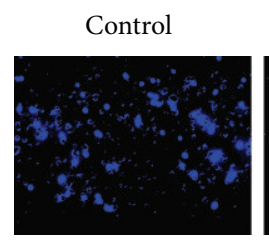

\begin{abstract}
RT $25 \mu \mathrm{M}$
\end{abstract}
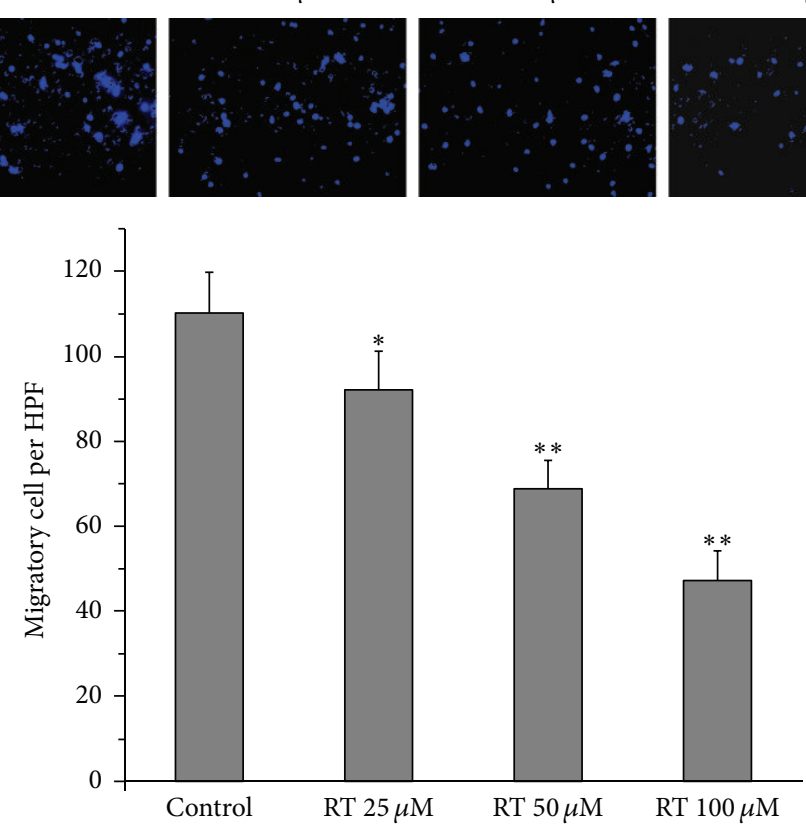

(b)

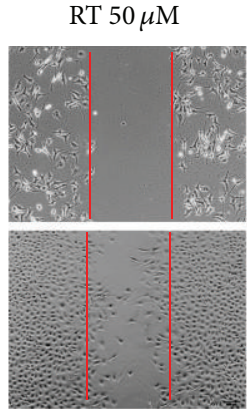

RT $50 \mu \mathrm{M}$
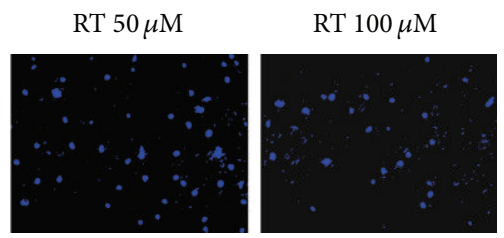
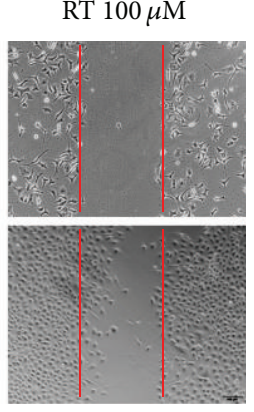

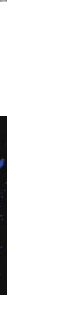

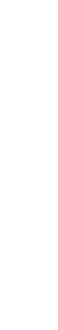



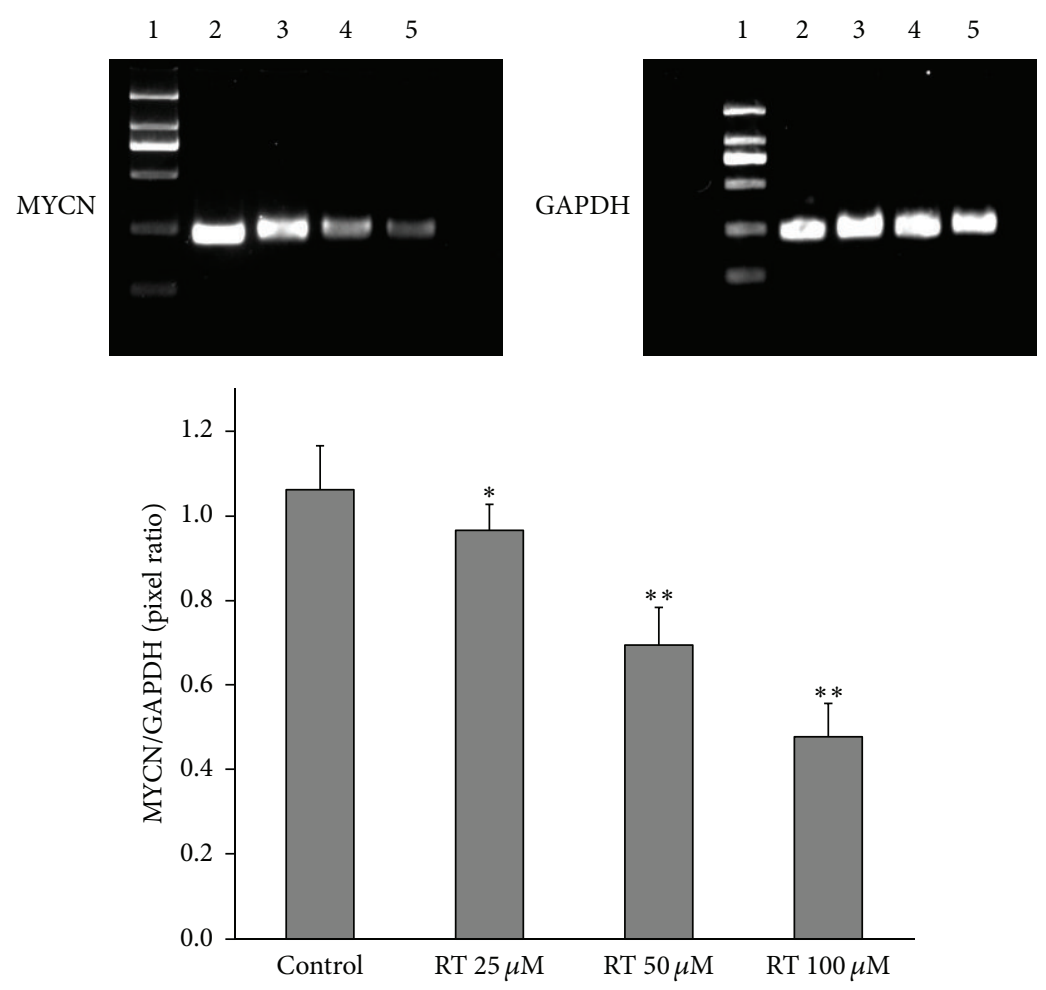

FiguRE 7: The effect of rutin on expression of MYCN. MYCN mRNA expression is high in normal cells, rutin significantly reduces MYCN mRNA expression in LAN-5. ${ }^{*} P<0.05 ;{ }^{* *} P<0.01$ compared to control. 1: marker; 2: control; 3: RT $25 \mu \mathrm{M}$; 4 : RT $50 \mu \mathrm{M}$; 5 : RT $100 \mu \mathrm{M}$.

of various chronic diseases such as cancer, diabetes, hypertension, and hypercholesterolemia [12]. Its use is advantageous over other flavonoids as it is a nontoxic and nonoxidizable molecule [13]. In the present study, we demonstrated that rutin suppressed cells proliferation by inducing G2/M cell cycle arrest and promoting apoptosis in LAN-5 cells.

The main biological characteristics of tumor cells are uncontrolled proliferation and higher migration ability. The MTT assay confirmed that rutin significantly suppressed LAN-5 cell proliferation and viability in a concentrationdependent manner. This study show that that rutin-treated LAN-5 cells have a decreased migratory capacity in scratch wound assay and transwell assay. The cell cycle is the series of events that take place in a cell leading to its division and duplication (replication); regulation of the cell cycle involves processes crucial to the survival of a cell. The previous studies reported showed that flavonoids promote cell cycle arrest in distinct phases is main effect on anticancer [14]. Our results indicated that rutin induced G2/M phase arrest in LAN-5 cells. Cell cycle regulation is also important in mediating radiosensitivity. Cells are most sensitive to radiation during the G2/M phase, less sensitive during G1, and least sensitive near the end of the $S$ phase [15]. These results indicate that rutin acts on the G2/M transition checkpoint of the cell cycle. The G2/M phase arrest cells are inclined to radiation-induced apoptosis; therefore, rutin may be a contributing factor in the increased radiosensitivity.

Cancer occurs as the result of a disturbance in the homeostatic balance between cell growth and cell death. Overexpression of antiapoptotic genes and underexpression of proapoptotic genes can result in the lack of cell death that is characteristic of cancer. Apoptosis was the major reason of cell death induced by antitumor drugs and radiosensitization drugs. The B cell lymphoma/leukemia-2 gene (BCL2) and the $\mathrm{Bcl} 2$-associated $\mathrm{X}$ protein gene (BAX) are an oncogene and a cancer suppressor gene, respectively. In many pathological studies, an unbalanced BCL2/BAX ratio (BCL2/BAX $>1$ ) has been recognized as a signature of the acquisition of apoptosis resistance in cancer cells $[16,17]$. Our study show that rutin could induce LAN-5 apoptosis and decrease BCL2 expression and BCL2/BAX ratio. This evidence indicates that the rutin has regulatory role in the BCL2/BAX balance of tumor cells. TNF- $\alpha$, being an endogenous pyrogen, is able to induce fever, apoptotic cell death, cachexia, and inflammation and to inhibit tumorigenesis and viral replication. The present repotted pictogram quantities of TNF- $\alpha$ are also produced by the malignant cell of advanced cancer its presence often being associated with poor prognostic factors [18]. In our study, we found that pictogram quantities of TNF- $\alpha$ are produced in LAN-5; rutin induced higher TNF- $\alpha$ secretion. These results suggest that rutin regulation of $B C L 2 / B A X$ balance and induced high levels of TNF- $\alpha$ secretion is a key role in inducing the apoptosis of tumor cell.

The MYCN gene is a member of the MYC family of transcription factors and encodes a protein with a basic helixloop-helix (bHLH) domain. Deregulated MYC expression is a key event for malignant transformation by inducing multiple tumor-promoting events, including uncontrolled cell proliferation, cell mass expansion, and genomic instability, and contributes to the genesis of a large number of human cancers 
[19-21]. In neuroblastoma, MYCN amplification occurs in approximately $25 \%$ of neuroblastoma cases; MYCN oncogene activation through amplification is an important hallmark of advanced tumor stage and poor prognosis [22]. Importantly, downregulation of MYCN expression results in apoptosis, decreased proliferation, and/or neuronal differentiation in $\mathrm{NB}$ cells in vitro [23, 24]. Consequently, MYCN is an attractive target for therapy in high-risk NB. In our study, we found that rutin could down regulate the expression of MYCN in a dose-dependent manner.

In conclusion, our study demonstrated that rutin plays the antiproliferation of human neuroblastoma cells role through inducing $\mathrm{G} 2 / \mathrm{M}$ phase cell cycle arrest and triggering apoptosis; this event is a BCL2-independent process. Moreover, rutin could inhibit MYCN expression. Rutin is a potential therapeutic drug for the treatment of neuroblastoma, particularly in MYCN expression tumor.

\section{Authors' Contribution}

Hongyan Chen and Qing Miao contributed to the work equally and should be regarded as co-first authors.

\section{Acknowledgments}

This work was supported by the National Natural Science Foundation (Grant no. 81041206) of China and the Traditional Medicine Special Project of PLA of China (Grant no. 10ZYZ244).

\section{References}

[1] J. M. Maris, "Recent advances in neuroblastoma," The New England Journal of Medicine, vol. 362, no. 23, pp. 2154-2211, 2010.

[2] S. Mueller and K. K. Matthay, "Neuroblastoma: biology and staging," Current Oncology Reports, vol. 11, no. 6, pp. 431-438, 2009.

[3] L. Jia, S. Ma, X. Hou et al., "The synergistic effects of traditional Chinese herbs and radiotherapy for cancer treatment," Oncology Letters, vol. 5, no. 5, pp. 1439-1447, 2013.

[4] S. H. Nile and S. W. Park, "Edible berries: review on bioactive components and their effect on human health," Nutrition, 2013.

[5] H. Hoensch and R. Oertel, "Anti-inflammatory effects of teaflavonoids," Deutsche Medizinische Wochenschrift, vol. 137, no. 51-52, pp. 2738-2740, 2012.

[6] M. S. Geybels, B. A. Verhage, I. C. Arts, F. J. van Schooten, R. A. Goldbohm, and P. A. van den Brandt, "Dietary flavonoid intake, black tea consumption, and risk of overall and advanced stage prostate cancer," American Journal of Epidemiology, vol. 177, no. 12, pp. 1388-1398, 2013.

[7] K. Evans, "Flavonoids in fruits, vegetables and nuts dramatically lower cancer rates," Tags: cancer, flavonoids, health news, September 2011.

[8] H. J. Chan, Y. L. Ji, H. C. Chul, and J. K. Chang, "Anti-asthmatic action of quercetin and rutin in conscious guinea-pigs challenged with aerosolized ovalbumin," Archives of Pharmacal Research, vol. 30, no. 12, pp. 1599-1607, 2007.

[9] S. R. Volate, D. M. Davenport, S. J. Muga, and M. J. Wargovich, "Modulation of aberrant crypt foci and apoptosis by dietary herbal supplements (quercetin, curcumin, silymarin, ginseng and rutin)," Carcinogenesis, vol. 26, no. 8, pp. 1450-1456, 2005.

[10] G. Yue, J. Wei, X. Qian et al., "Synergistic anticancer effects of polyphyllin and evodiamine on freshly-removed human gastric tumors," PLoS ONE, vol. 8, no. 6, Article ID e65164, 2013.

[11] X. Yan, T. Lyu, N. Jia, Y. Yu, K. Hua, and W. Feng, "Huaier aqueous extract inhibits ovarian cancer cell motility via the AKT/GSK3 $\beta / \beta$-catenin pathway," PLoS ONE, vol. 8, no. 5, Article ID e63731, 2013.

[12] A. Hunyadi, A. Martins, T. J. Hsieh, A. Seres, and I. Zupkó, "Chlorogenic acid and rutin play a major role in the in vivo antidiabetic activity of Morus alba leaf extract on type II diabetic rats," PLoS ONE, vol. 7, no. 11, Article ID e50619, 2012.

[13] S. Sharma, A. Ali, J. Ali, J. K. Sahni, and S. Baboota, "Rutin: therapeutic potential and recent advances in drug delivery," Expert Opinion on Investigational Drugs, vol. 22, no. 8, pp. 10631079, 2013.

[14] M. Majewska-Wierzbicka and H. Czeczot, "Anticancer activity of flavonoids," Polski Merkuriusz Lekarski, vol. 33, no. 198, pp. 364-369, 2012.

[15] Y. Zhao, W. Jiang, B. Li et al., "Artesunate enhances radiosensitivity of human non-small cell lung cancer A549 cells via increasing NO production to induce cell cycle arrest at G2/M phase," International Immunopharmacology, vol. 11, no. 12, pp. 2039-2046, 2011.

[16] M. Zhang, P. Zhang, C. Zhang et al., "Prognostic significance of $\mathrm{Bcl}-2$ and Bax protein expression in the patients with oral squamous cell carcinoma," Journal of Oral Pathology and Medicine, vol. 38, no. 3, pp. 307-313, 2009.

[17] A. Faggiano, J.-C. Sabourin, M. Ducreux et al., "Pulmonary and extrapulmonary poorly differentiated large cell neuroendocrine carcinomas: diagnostic and prognostic features," Cancer, vol. 110, no. 2, pp. 265-274, 2007.

[18] H. Kulbe, R. Thompson, J. L. Wilson et al., "The inflammatory cytokine tumor necrosis factor- $\alpha$ generates an autocrine tumorpromoting network in epithelial ovarian cancer cells," Cancer Research, vol. 67, no. 2, pp. 585-592, 2007.

[19] M. Eilers and R. N. Eisenman, "Myc's broad reach," Genes and Development, vol. 22, no. 20, pp. 2755-2766, 2008.

[20] N. Meyer and L. Z. Penn, "Reflecting on 25 years with MYC," Nature Reviews Cancer, vol. 8, no. 12, pp. 976-990, 2008.

[21] M. Vita and M. Henriksson, "The Myc oncoprotein as a therapeutic target for human cancer," Seminars in Cancer Biology, vol. 16, no. 4, pp. 318-330, 2006.

[22] M. Huang and W. A. Weiss, "Neuroblastoma and MYCN," Cold Spring Harbor Perspectives in Medicine, vol. 3, no. 10, Article ID 014415, 2013.

[23] A. Edsjö, L. Holmquist, and S. Påhlman, "Neuroblastoma as an experimental model for neuronal differentiation and hypoxiainduced tumor cell dedifferentiation," Seminars in Cancer Biology, vol. 17, no. 3, pp. 248-256, 2007.

[24] U. K. Westermark, M. Wilhelm, A. Frenzel, and M. A. Henriksson, "The MYCN oncogene and differentiation in neuroblastoma," Seminars in Cancer Biology, vol. 21, no. 4, pp. 256-266, 2011. 

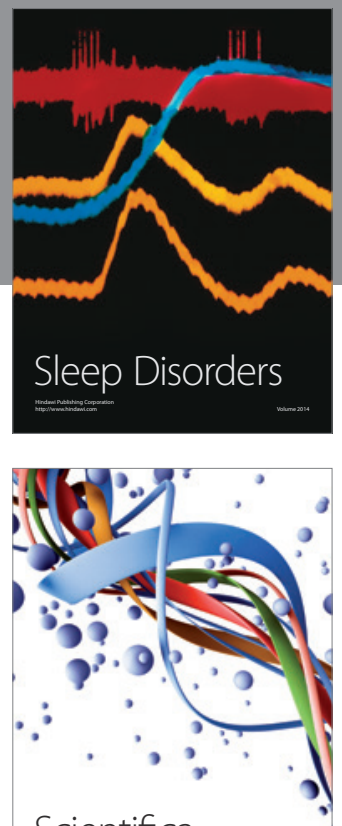

Scientifica
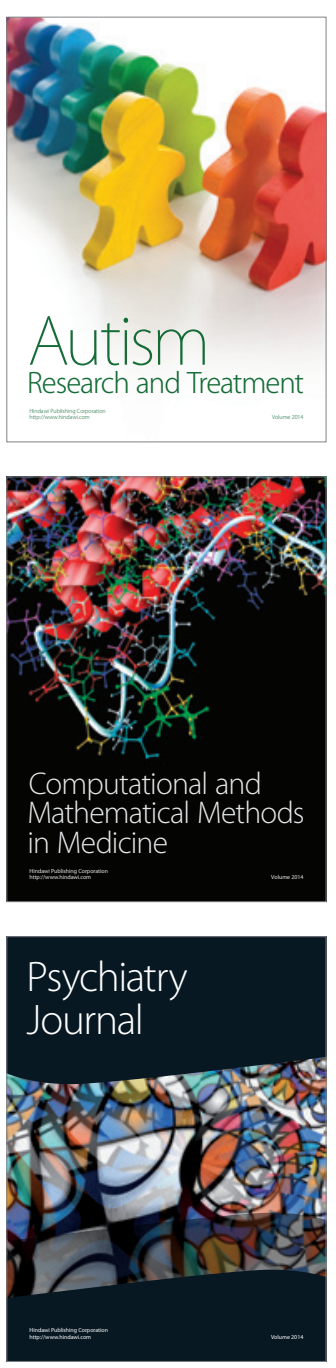
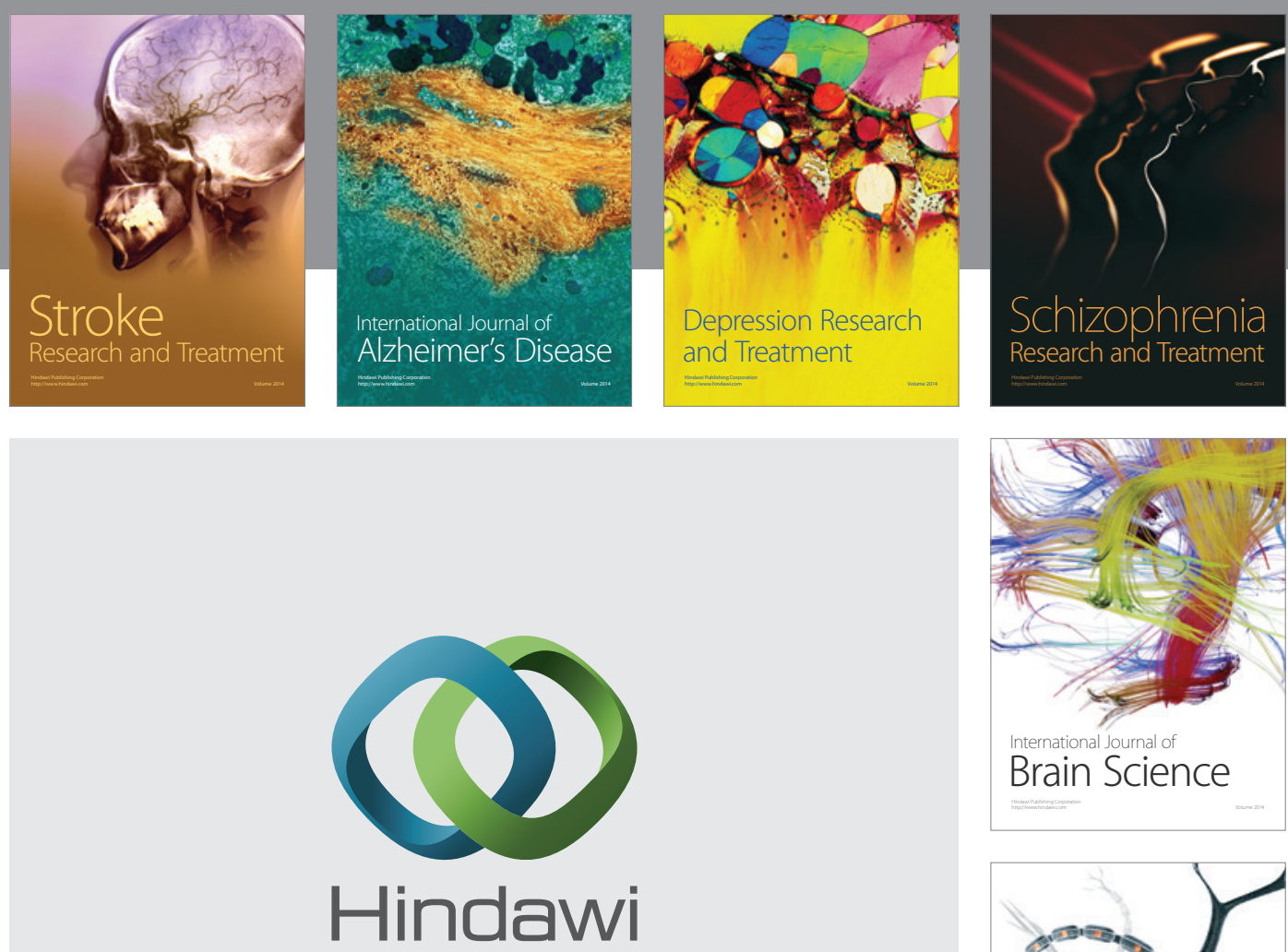

Submit your manuscripts at

http://www.hindawi.com
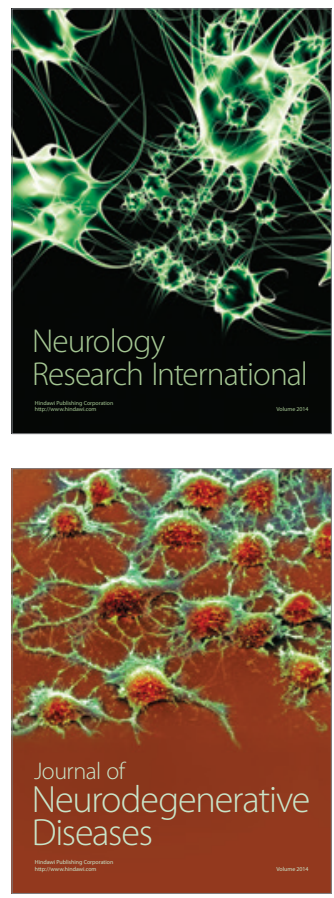

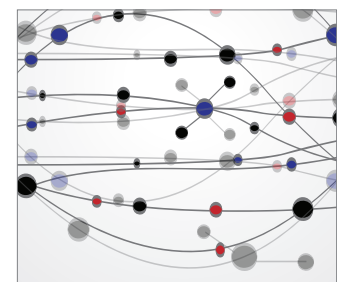

The Scientific World Journal
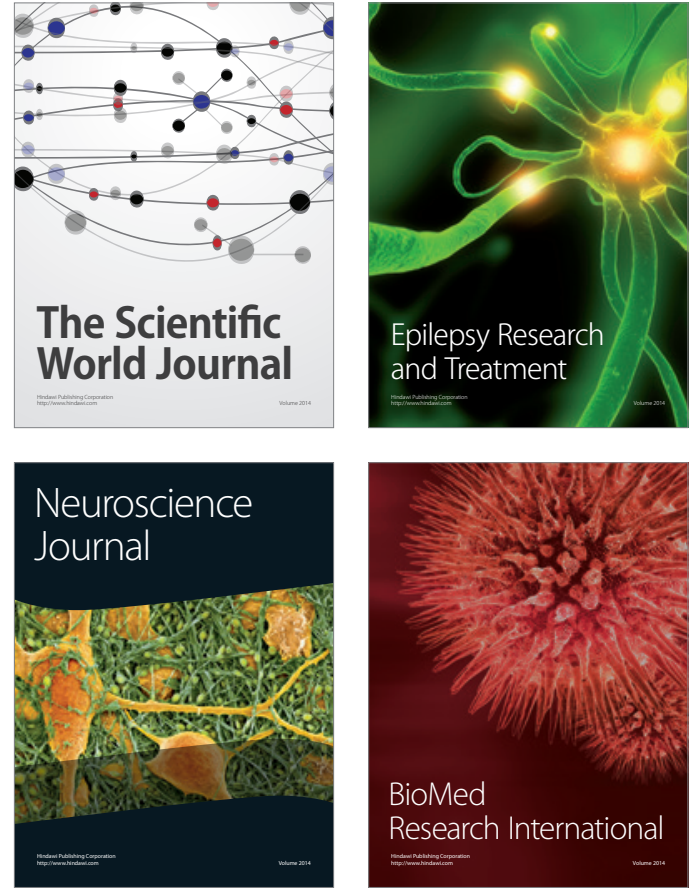

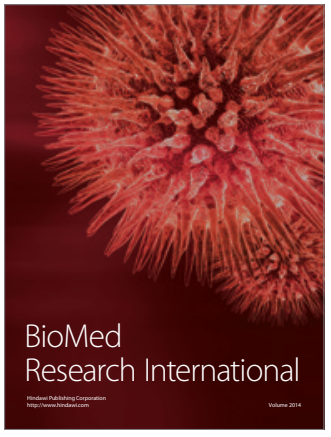

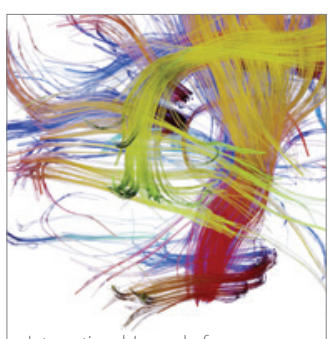

Brain Science

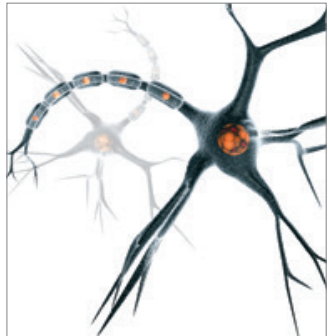

Neural Plasticity
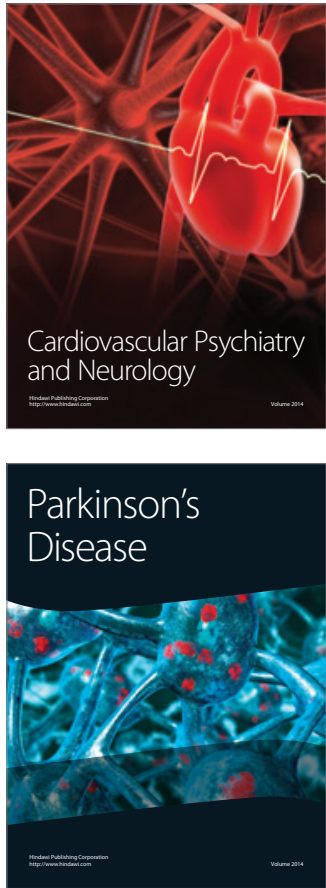